\title{
Review Article \\ Role of Policies and Laws of the Country in the Activities of Exploiting and Using the East Sea
}

\author{
Do Duc Minh ${ }^{1, *}$, Quach Thi Hue ${ }^{2}$ \\ ${ }^{1}$ VNU School of Law, Vietnam National University, Hanoi, \\ 144 Xuan Thuy, Cau Giay, Hanoi, Vietnam \\ ${ }^{2}$ Internation Relations Institute, Ho Chi Minh National Academay of Politics, \\ 135 Nguyen Phong Sac, Cau Giay, Hanoi, Vietnam \\ Received 16 March 2020 \\ Revised 15 April 2020; Accepted 26 June 2020
}

\begin{abstract}
The paper focuses on research and commentary clarifying some basic theoretical issues about marine policy and law; analyze current situation of policies and laws in the East Sea currently; From there, generalizing matters with methodological significance to identify and confirm the role of national policies and laws on the use and exploitation of the East Sea in the current context.
\end{abstract}

Keywords: role, policy, law, South China sea.

\footnotetext{
* Corresponding author.

Email address: ducminhtuhp@gmail.com

https://doi.org/10.25073/2588-1167/vnuls.4286
} 


\title{
Vai trò chính sách, pháp luật các quốc gia trong hoạt động khai thác, sử dụng Biển Đông
}

\author{
Đỗ Đức Minh ${ }^{1, *}$, Quách Thị Huệ ${ }^{2}$ \\ ${ }^{1}$ Khoa Luật, Đại học Quốc gia Hà Nội, 144 Xuân Thủy, Cầu Giấy, Hà Nội, Việt Nam \\ ${ }^{2}$ Viện Quan hệ Quốc tế, Học viện Chính trị Quốc gia Hồ Chí Minh, \\ 135 Nguyễn Phong Sắc, Cầu Giấy, Hà Nội, Việt Nam \\ Nhận ngày 16 tháng 03 năm 2020 \\ Chỉnh sửa ngày 15 tháng 4 năm 2020; Chấp nhận đăng ngày 26 tháng 6 năm 2020
}

\begin{abstract}
Tóm tắt: Bài viết tập trung nghiên cứu, luận giải làm rõ một số vấn đề lí luận cơ bản về chính sách và pháp luật biển; phân tích tình hình thực tiễn chính sách, pháp luật ở Biển Đông; từ đó, khái quát những vấn đề có ý nghĩa phương pháp luận để nhận diện và khẳng định vai trò của chính sách, pháp luật các quốc gia về sử dụng, khai thác Biển Đông trong bối cảnh hiện nay.
\end{abstract}

Tù khóa: vai trò, chính sách, pháp luật, Biển Đông.

\section{Chính sách và pháp luật biển}

Biển và đại dương có tầm quan trọng đặc biệt về kinh tế - chính trị xã hội và là xu hướng phát triển chủ yếu đối với các nước trên thế giới. Thế kỉ XXI được coi là kỉ nguyên của "Biển và Đại dương", "Biển và Kinh tế biển",... Trước sự dịch chuyển địa chiến lược từ không gian đất liền ra không gian biển, trong thời gian gần đây nhiều quốc gia đã tiến hành hoạch định chiến lược biển của mình. Đồng thời, để thích nghi, ứng phó với sự thay đổi lớn trên thế giới, bảo vệ lợi ích và chủ quyền quốc gia, các quốc gia đều có sự điều chỉnh chiến lược biển, đặt chiến lược biển vào vị trí trung tâm của chiến lược quốc gia.

\section{Chính sách biển}

Là tổng thể các quan điểm, chuẩn mực, sách lược, nội dung và phương pháp hành động của nhà nước nhằm thực hiện thắng lợi chiến lược, đường lối của quốc gia về quản lí, khai thác và sử dụng biển đảo, phát triển kinh tế biển và đảm bảo quốc phòng - an ninh trên biển đảo, hợp tác quốc tế về biển, phân định biển, bảo vệ và gìn giữ môi trường biển. Chính sách biển cũng được xem như là biện pháp hữu hiệu để các quốc gia ven biển triển khai thực hiện nhằm đạt được những mục tiêu bảo vệ chủ quyền biển và phát triển kinh tế biển (mục tiêu hàng đầu), gắn liền giữa công tác quản lí biển với việc khai thác biển đảo. Từ những yêu cầu này, các quốc gia ven biển đã hoạch định chính sách biển, ban hành các văn bản quy phạm pháp luật để quy định cách thức thực hiện các biện pháp bảo vệ chủ quyền biển đảo, phát triển các lĩnh vực kinh tế biển đồng thời ngăn chặn những nguy cơ xâm phạm chủ quyền biển đảo đến từ bên ngoài.

Nội dung của chính sách biển rộng lớn và phong phú, bao gồm: Xây dựng, khôi phục và duy trì vị thế cường quốc biển, phát triển và mở rộng ra biển để trở thành cường quốc biển, củng cố sức mạnh quốc gia. Thực thi chiến lược kinh tế, an ninh từ biển, kết hợp giữa phát triển kinh tế biển với quốc phòng - an ninh, tăng cường sức

\footnotetext{
* Tác giả liên hệ.

Địa chỉ email: ducminhtuhp@gmail.com

https://doi.org/10.25073/2588-1167/vnuls.4286
} 
mạnh quân sự, bảo đảm an toàn và an ninh trên biển. Đảm bảo hoạt động của các lực lượng thực thi pháp luật trên biển (hải quân, cảnh sát biển, kiểm ngư, biên phòng,...), quyền tự do hàng hải, hàng không của các quốc gia. Phát triển kinh tế biển nhằm khai thác và quản lí các nguồn lực từ biển, phát triển tài nguyên biển; thúc đẩy, tăng cường nghiên cứu khoa học về biển, các hoạt động trong nghiên cứu và phát triển liên quan đến biển, thăm dò đại dương; phát triển các ngành kinh tế biển (dầu khí; phát triển cảng biển và giao thông hàng hải; nuôi trồng, khai thác, chế biến thủy hải sản; du lịch dịch vụ biển; khai thác sa khoáng sản ven biển; phát triển mới các khu kinh tế và khu công nghiệp ven biển); kết hợp hài hòa giữa khai thác tài nguyên và bảo vệ môi trường biển, khai thác và bảo vệ tài nguyên đại dương; "đầu tư phát triển" hệ thống kết cấu hạ tầng phục vụ cho kinh tế biển.

\subsection{Luật biển}

Là một trong những ngành độc lập trong hệ thống pháp luật quốc tế xuất hiện từ thời xưa và có vai trò quan trọng trong đời sống quan hệ quốc tế. Lúc đầu mới hình thành, luật biển tồn tại dưới dạng những tập quán quốc tế chỉ được một số quốc gia thừa nhận và vận dụng. Trải qua quá trình lâu dài hợp tác và đấu tranh giữa các quốc gia, luật biển ngày càng phát triển và hoàn thiện tạo nên môi trường pháp lí cho cộng đồng quốc tế trong việc quản lí, khai thác và sử dụng biển có hiệu quả, điển hình là sự ra đời của công ước quốc tế lớn về luật biển như Công ước luật biển năm 1958 và năm 1982.

Các nguyên tắc cơ bản của luật biển quốc tế, gồm: Nguyên tắc tự do biển cả; Nguyên tắc đất thống trị biển; Nguyên tắc di sản chung của loài người; Nguyên tắc sử dụng biển cả vì mục đích hòa bình; Nguyên tắc sử dụng hợp lí và bảo vệ sinh vật sống trên biển; Nguyên tắc bảo vệ môi trường biển.

Trong đó, nguyên tắc tự do biển cả là nguyên tắc cổ điển, được pháp điển hóa trở thành nguyên tắc cơ bản của Công ước Liên Hợp quốc về Luật Biển năm và đồng thời vẫn tồn tại với tư cách là một tập quán quốc tế. Do đặc trưng không thuộc sở hữu của bất kì quốc gia nào nên quy chế pháp lí của biển cả là quy chế tự do, được hiểu theo hai khía cạnh: (i) Thừa nhận sự ngang nhau về quyền lợi và lợi ích của mọi quốc gia trên biển cả; (ii) Không có sự phân biệt đối xử dựa trên hoàn cảnh địa lí của mọi quốc gia khi tham gia sử dụng và khai thác biển cả. Bản chất pháp lí này thể hiện và đảm bảo bằng nội dung của nguyên tắc tự do biển cả: biển cả được để ngỏ cho tất cả các quốc gia, dù có biển hay không có biển. Quyền tự do trên biển cả được thực hiện trong những điều kiện do các quy định của Công ước và những quy tắc khác của pháp luật quốc tế trù định.

Trong vùng đặc quyền về kinh tế, tất cả các quốc gia, dù có biển hay không có biển, được hưởng các quyền tự do hàng hải và hàng không, quyền tự do đặt dây cáp ngầm cũng như quyền tự do sử dụng biển vào những mục đích khác hợp pháp về mặt quốc tế và gắn liền với việc thực hiện các quyền tự do này và phù hợp với các quy định khác của Công ước về Luật biển, nhất là những khuôn khổ trong việc khai thác các tàu thuyền, phương tiện bay và dây cáp, ống dẫn ngầm. Đối với tất cả những vùng biển không nằm trong vùng đặc quyền về kinh tế, lãnh hải hay nội thủy của một quốc gia cũng như không nằm trong vùng nước quần đảo của một quốc gia quần đảo; sẽ không hạn chế về bất cứ phương diện nào các quyền tự do mà tất cả các quốc gia được hưởng trong vùng đặc quyền về kinh tế (Điều 86).

Theo quy định tại điều 87 Công ước Luật biển năm 1982, nguyên tắc tự do biển cả được cụ thể hóa thành các quyền cơ bản:

- Tự do hàng hải: đây là quyền tự do truyền thống, quan trọng nhất để phân biệt tính chất pháp lí của biển cả với những vùng biển thuộc chủ quyền và quyền tài phán của quốc gia ven biển, liên quan trực tiếp đến tàu thuyền mang quốc tịch của các quốc gia;

- Khi hoạt động trong vùng biển cả, nguyên tắc tự do biển cả có ý nghĩa tạo ra cho tàu một nước nhất định không phải chịu sự tài phán của một quốc gia khác, trừ quốc gia mà tàu mang quốc tịch. Theo quy chế tự do này, tàu thuyền quân sự của mỗi quốc gia hoạt động trên biển quốc tế bên cạnh quyền miễn trừ tư pháp đối với 
tàu thuyền vi phạm của nước mình hoặc của những tàu thuyền có các hành vi vi phạm theo quy định trong công ước Luật biển năm 1982;

- Các quyền tự do khác: tự do biển cả được để ngỏ cho tất cả các quốc gia dù có biển hay không có biển có những quyền tự do trong sử dụng biển cũng như hưởng lợi ích từ biển cả. Đó là những quyền tự do hàng không, tự do đặt dây cáp và ống dẫn ngầm, tự do xây dựng các đảo nhân tạo hoặc các thiết bị được pháp luật quốc tế cho phép, tự do đánh bắt hải sản, tự do nghiên cứu khoa học biển,...

Công ước Liên Hợp quốc về Luật biển năm 1982 cũng khẳng định: Biển cả được sử dụng vào các mục đích hòa bình (Điều 88 ). Nguyên tắc tự do biển cả không cho phép bất cứ quốc gia nào có thể đòi đặt một cách hợp pháp một bộ phận nào đó của biển cả thuộc vào chủ quyền của mình (Điều 89). Điều này có nghĩa là trong biển cả tất cả các quốc gia đều được hưởng các quyền tự do được quy định trong luật quốc tế. Tuy nhiên, để tránh tình trạng tự do vô hạn hoặc sử dụng biển cả tùy tiện thì mỗi quốc gia khi thực hiện các quyền tự do này phải tôn trọng quyền lợi và tính đến lợi ích của việc thực hiện tự do trên biển cả của các quốc gia khác cũng như đến các quyền được Công ước thừa nhận liên quan đến các hoạt động trong Vùng.

\section{Chính sách, pháp luật (các) quốc gia trong hoạt động khai thác, sử dụng Biển Đông}

\subsection{Biển Đông}

\section{Khái quát tình hình Biển Đông}

Với diện tích gần $3.000 .000 \mathrm{~km}^{2}$, Biển Đông là biển nửa kín lớn hàng đầu trên thế giới. Biển Đông có tầm quan trọng chiến lược đối với các quốc gia trong và ngoài khu vực nhưng cũng ẩn chứa nguy cơ xung đột do những tranh chấp về chủ quyền lãnh thổ và vùng biển dai dẳng giữa các quốc gia trong khu vực.

\footnotetext{
${ }^{1}$ Hơn $1 / 2$ lượng hàng hóa vận chuyển bằng tàu biển hàng năm của thế giới đi qua eo biển Malacca, eo biển Sunda và eo biển Lombok, với đa số các tàu này tiếp tục hành trình vào Biển Đông. Lượng tàu chở dầu đi qua eo biển Malacca
}

"Vị thế Biển Đông trên bình đồ châu Á và thế giới được đánh giá theo 3 tiêu chí là vị thế tự nhiên, vị thế địa kinh tế và vị thế địa chính trị. Về địa kinh tế, Biển Đông sở hữu một nguồn tài nguyên lớn cho các dân tộc xung quanh, là con đường hàng hải huyết mạch cho nhiều nước trên thế giới, đồng thời cũng thể hiện rõ sự chênh lệch rất lớn về tiềm lực kinh tế của các nước bao quanh, từ đó nảy sinh nhiều cách ứng xử khác nhau đối với chính sách Biển Đông. Về địa chính trị, do vị trí "ngã tư" và "trung tâm" của mình, khu vực là nơi giao thoa của nhiều nền văn hóa, là mảnh đất của chế độ thực dân cũ và mới, là nơi đối đầu trong chiến tranh lạnh và là nơi có một vị thế địa quân sự mang tầm quốc tế. Khu vực Biển Đông trở thành một trong những nơi hội tụ lợi ích then chốt của các nước bởi tiềm năng kinh tế, an ninh chiến lược cũng như vị thế địa chính trị đang nổi lên hiện nay.

Đối với 9 quốc gia ven biển, gồm Trung Quốc (kể cả Đài Loan) về phía Bắc; Philippin ở phía Đông; Malaixia, Singapo, Indonexia và Brunay ở phía Nam; Thái Lan, Campuchia và Việt Nam ở phía Tây, Biển Đông có giá trị to lớn về mặt kinh tế, xã hội và môi trường. Tiềm năng kinh tế nổi bật và thường được đề cập đến của Biển Đông là tài nguyên dầu khí, tài nguyên sinh vật - hải sản đa dạng sinh học và địa điểm du lịch lí tưởng. Là cầu nối giữa Ấn Độ Dương và Thái Bình Dương, xuyên qua Biển Đông có những tuyến hàng hải vô cùng quan trọng, đông đúc phục vụ cho việc vận tải hơn $1 / 4$ khối lượng thương mại toàn cầu. Là một trong những tuyến hàng hải huyết mạch quan trọng, bận rộn, đông đúc nhất trên thế giới với 3.400 tỉ lưu lượng hàng hóa vận chuyển hàng năm ${ }^{1}$, tuyến hàng hải qua Biển Đông trước hết có ý nghĩa thiết yếu đối với việc vận hàng hóa xuất nhập khẩu của các quốc gia trong và ngoài khu vực, đặc biệt đối với Trung Quốc, Hàn Quốc, Nhật Bản, Ức và Châu Phi. Biển Đông còn có ý nghĩa kinh tế và địa chính quan trọng đối với Mĩ - quốc gia có nhiều công ty dầu khí hoạt động khai thác

để vào Biển Đông nhiều hơn 3 lần số tàu loại này qua kênh đào Suez, hơn 5 lần số lượt loại tàu này qua kênh đào Panama. 
trong khu vực đồng thời duy trì ưu thế hải quân trên phạm vi toàn cầu.

\subsection{Tranh chấp chủ quyền trên Biển Đông}

\section{a) Bối cảnh}

Tranh chấp chủ quyền trên Biển Đông bao gồm các tranh chấp về đảo (quần đảo Hoàng $\mathrm{Sa}$ và quần đảo Trường $\mathrm{Sa}$ ) và vùng biển ${ }^{2}$. Ngoài ra, vùng biển trong khu vực Biển Đông cũng là đối tượng tranh chấp giữa các quốc gia về ngư trường, khai thác tài nguyên (đặc biệt là dầu khí) và kiểm soát của một vị trí chiển lược. Các quốc gia gián tiếp can dự đáng kể đến Biển Đông là Hoa Kỳ, Nhật Bản, Úc và Ân Độ.

Các tranh chấp về chủ quyền trên Biển Đông giữa các quốc gia trong khu vực diễn ra từ sau Chiến tranh Thế giới lần thứ II. Ban đầu các quốc gia tranh chấp vì vị trí chiến lược của Biển Đông [1]. Đối với Trung Quốc, Biển Đông nói chung cũng như quần đảo Hoàng $\mathrm{Sa}$ và quần đảo Trường $\mathrm{Sa}$ có vị trí quan trọng do nằm giữa Ân Độ Dương và Thái Bình Dương là một vùng chiến lược quan trọng, là cổng của lục địa Trung Quốc đi ra thế giới bên ngoài [2]. Với Nhật Bản, Biển Đông là con đường giao thông huyết mạch không chỉ với Đông Nam Á mà cả với Trung Đông và châu Âu. Nền kinh tế Nhật Bản gắn liền với sự giao thông này. Vì lợi ích chiến lược, trong Chiến tranh Thế giới lần thứ II Nhật đã cho xây căn cứ tàu ngầm tại đảo Ba Bình thuộc quần đảo Trường Sa.

Tiếp theo, sau khi Công ước Liên Hợp quốc về Luật biển năm 1982 quy định về vùng đặc quyền kinh tế thì tầm quan trọng của việc khai thác tài nguyên, chủ yếu là đánh cá và khai thác dầu khí là nguyên nhân bổ sung cho mục đích tranh chấp [3] (các cơ hội đánh bắt cá phong phú cũng là một động lực cho yêu sách chủ quyền).

\footnotetext{
${ }^{2}$ Quần đảo Trường $\mathrm{Sa}$ và quần đảo Hoàng $\mathrm{Sa}$ là hai quần đảo trên các rạn san hô ở Biển Đông, trong đó quần đảo Hoàng Sa đang là nơi tranh chấp chủ quyền giữa Việt Nam, Trung Quốc và Đài Loan. Quần đảo Trường Sa là nơi tranh chấp chủ quyền của 6 quốc gia và lãnh thố: Trung Quốc, Đài Loan, Việt Nam, Philippines, Malaysia và Brunei; các quốc gia này tuyên bố chủ quyền toàn bộ hay một phần quần đảo Trường $\mathrm{Sa}$ (Trung Quốc gọi Hoàng $\mathrm{Sa}$ là quần đảo Tây $S a$ 西沙群岛 và Trường Sa là quần đảo Nam $\mathrm{Sa}$ 南沙群
}

Có rất nhiều tranh cãi về lãnh hải trên vùng Biển Đông và các nguồn tài nguyên của nó, bởi Công ước Luật Biển 1982 cho phép các nước có vùng đặc quyền kinh tế mở rộng 200 dặm biển $(370,6$ $\mathrm{km})$ từ lãnh hải của mình, nên các nước quanh vùng biển có thể đưa ra tuyên bố chủ quyền với những phần rộng lớn, tạo nên những vùng có nguy cơ tranh chấp gồm:

- Indonesia và Trung Quốc về vùng Biển Đông Bắc quần đảo Natuna;

- Philippines và Trung Quốc về những khu khai thác khí gas Malampaya và Camago;

- Philippines và Trung Quốc về bãi cạn Scarborough: tranh chấp chủ quyền về những khu khai thác khí gas Malampaya và Camago và về bãi cạn Scarborough.

- Việt Nam và Trung Quốc về vùng biển phía tây quần đảo Trường Sa. Một số hay toàn bộ quần đảo Trường $\mathrm{Sa}$ đang bị tranh chấp giữa Việt Nam, Trung Quốc, Đài Loan, Philippines và một số nước khác;

- Trung Quốc đang quản lí toàn bộ quần đảo Hoàng Sa dù Việt Nam và Đài Loan cũng tuyên bố chủ quyền;

- Malaysia, Campuchia, Thái Lan và Việt Nam về những vùng ở vịnh Thái Lan;

- Singapore và Malaysia dọc theo Eo biển Johore và Eo biển Singapore ${ }^{3}$.

Trong đó, cả Việt Nam và Trung Quốc đều tuyên bố mạnh mẽ chủ quyền đối với các quần đảo Hoàng Sa và Trường Sa. Năm 1932, chính quyền Pháp ở Đông Dương chiếm giữ quần đảo Hoàng $\mathrm{Sa}$ và sau đó là Việt Nam (Việt Nam Cộng hòa) tiếp tục nắm giữ chủ quyền cho đến năm 1974. Trung Quốc chiếm giữ hai đảo Phú Lâm và Lin Côn từ năm 1956 và hiện đang chiếm giữ toàn bộ Hoàng Sa từ sau trận Hải chiến Hoàng Sa (19/1/1974) và chiếm đóng

岛). Bãi Macclesfield là đối tượng tranh chấp giữa Trung Quốc và Philippines; Quần đảo Đông $S a$ 東沙群島 do Đài Loan quản lí là đối tượng tranh chấp giữa Trung Quốc và Đài Loan. Quần đảo Natuna do Indonesia tuyên bố chủ quyền cũng đang bị Trung Quốc đe dọa.

${ }^{3}$ Những tuyên bố lãnh thổ chồng lấn ở Pulau Pedra Branca hay Pulau Batu Putih của cả Singapore và Malaysia đã được đưa ra Tòa án quốc tế và Tòa án đã phán quyết theo hướng có lợi cho Singapore. 
một phần của Trường $\mathrm{Sa}$ từ sau ngày 14/3/1988 . Tiếp theo là hàng loạt các sự kiện nổi lên trong quan hệ Việt - Trung và các quốc gia có liên quan.

Các nước tranh chấp thường xuyên thông báo về các vụ va chạm giữa các tàu hải quân. ASEAN nói chung cũng như Trung Quốc luôn muốn đảm bảo rằng những tranh chấp bên trong Biển Đông sẽ không leo thang trở thành xung đột

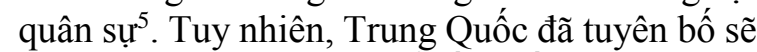
không ngại dùng vũ lự để lấy quần đảo Trường Sa. Điều đó cho thấy Trung Quốc có khả năng và sẵn sàng phản ứng rất mạnh mẽ với những hành động của các quốc gia khác mà Trung Quốc tin rằng làm ảnh hưởng đến quyền lợi của họ trên Biển Đông. Trung Quốc cũng phản đối sự can thiệp của các nước bên ngoài vào tình hình Biển Đông.

\section{b) Đưòng chín đoạn của Trung Quốc}

Là tên gọi dùng để chỉ đường biên giới trên Biển Đông mà Trung Quốc chủ trương và đơn phương tuyên bố chủ quyền. Năm 1947, chính phủ Trung Hoa Dân quốc đưa ra yêu sách chủ quyền trên Biển Đông với đường lưỡi bò 11 đoạn, và xuất hiện công khai lần đầu tiên vào tháng 2/1948 trong phụ lục "Bản đồ vị trí các đảo Nam Hải" của "Bản đồ khu vực hành chính Trung Hoa Dân quốc" do Cục Phương vực Bộ Nội chính Trung Hoa Dân quốc phát hành ${ }^{6}$. Cộng hòa Nhân dân Trung Hoa sau khi thành lập năm 1949 vẫn xác định cương vực trên Biển Đông theo "đường mười một đoạn" của Trung Hoa Dân quốc, đến năm 1953 thì bỏ hai đoạn trong vịnh Bắc Bộ, trở thành "đường chín đoạn". Đường chín đoạn bao trọn bốn nhóm

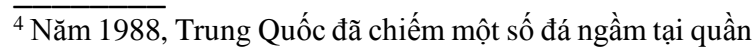
đảo Trường Sa; năm 1995, Trung Quốc chiếm đá ngầm Vành Khăn đang do Philippines kiểm soát.

${ }^{5}$ Vì vậy, các cơ chế cùng hợp tác phát triển đã được lập ra tại các vùng tranh chấp chồng lấn để cùng phát triển vùng và phân chia quyền lợi công bằng tuy nhiên không giải quyết vấn đề chủ quyền của vùng đó. Điều này đã trở thành sự thực ở Vịnh Thái Lan.

${ }^{6}$ Dường chín doạn (九段线, 九段線), Đường luõo bò, Đưòng chĩ $U$, Đường chín khúc. Đường này xuất hiện do thời điểm đó Trung Hoa Dân quốc không có khả năng đo lường các hòn đảo để xác định mọi địa hình tạo đường phân định cho khu vực hành chính xung quanh vì thế họ vẽ ra
}

quần đảo, bãi ngầm lớn trên Biển Đông là quần đảo Hoàng $\mathrm{Sa}$, quần đảo Trường $\mathrm{Sa}$, quần đảo Đông Sa và bãi Macclesfield với khoảng $75 \%$ diện tích mặt nước của Biển Đông, chỉ chừa lại khoảng $25 \%$ cho tất cả các nước Philippines, Malaysia, Brunei, Indonesia và Việt Nam được trung bình $5 \%$.

Các quốc gia Đông Nam Á có tranh chấp trên Biển Đông đã dựa vào Hiệp hội các quốc gia Đông Nam Á (ASEAN) như là một trung gian để giải quyết tranh chấp giữa Trung Quốc và các thành viên của ASEAN. Các thỏa thuận giữa các quốc gia ASEAN và Trung Quốc bao gồm các cam kết thông báo cho nhau về bất kì động thái quân sự tại khu vực tranh chấp và tránh xây dựng thêm công trình mới trên các hòn đảo. Trung Quốc và $A S E A N$ cũng đã bắt đầu các cuộc đàm phán nhằm tạo ra một quy tắc ứng xử nhằm giảm bớt căng thẳng đối với quần đảo tranh chấp, đã thống nhất Tuyên bố về cách ứng xử các bên trên Biển Đông. Tháng 7/2011, Trung Quốc, Brunei, Malaysia, Philippines, Đài Loan và Việt Nam đã đồng ý với một bộ chỉ dẫn sơ bộ nhằm giải quyết tranh chấp. Tài liệu này được xem là "một cột mốc quan trọng thể hiện cho sự hợp tác giữa Trung Quốc và các nước ASEAN". Một số nội dung của tài liệu như "bảo vệ môi trường biển, nghiên cứu khoa học, an toàn hàng hải và thông tin liên lạc, tìm kiếm cứu nạn và đấu tranh chống tội phạm xuyên quốc gia" (tuy nhiên vấn đề khai thác dầu khí và khí thiên nhiên vẫn chưa được giải quyết) $)^{7}$.

Nhìn chung, ở Biển Đông tồn tại chủ yếu 2 loại tranh chấp về biên giới, lãnh thổ, là tranh chấp về chủ quyền đảo và tranh chấp về phân

đường chạy qua điểm giữa các hòn đảo và vùng đất lân bang để chỉ ra rằng các đảo nằm bên trong đường vẽ ra là lãnh thổ Trung Hoa. Đường này chạy qua điểm trung tuyến giữa các điểm nhô ra nhất của các hòn đảo và địa hình của đất liền xung quanh. Không hề có các tọa độ địa lí cụ thể được nêu ra và những bản đồ mỗi thời in đường mười một đoạn này lại khác nhau.

${ }^{7}$ Một điểm cần lưu ý là Trung Quốc luôn luôn chủ trương chỉ đối thoại song phương và tìm thỏa thuận với từng quốc gia tranh chấp trong khi một số quốc gia Đông Nam Á lại chủ trương đa phương hóa và quốc tế hóa vấn đề tranh chấp. Trung Quốc nhiều lần tìm cách áp lực lên ASEAN để tránh sự liên kết của những quốc gia thành viên chống lại họ. 
định ranh giới các vùng biển (bao gồm cả thềm lục địa). Tranh chấp về chủ quyền đảo liên quan đến lịch sử chiếm hữu và quản lý các đảo, đá, bãi ngầm thuộc hai quần đảo Hoàng $\mathrm{Sa}$ và Trường Sa nằm ở khu trung tâm Biển Đông; các tranh chấp ranh giới vùng biển bắt nguồn từ việc quốc gia ven biển mở rộng phạm vi các vùng biển của mình theo quy định của Công ước của Liên Hợp quốc về Luật Biển 1982. Từ góc độ pháp lí, hai loại tranh chấp này về cơ bản được giải quyết trên hai cơ sở khác nhau. Tuy nhiên, trên thực tế tranh chấp về chủ quyền đảo thường liên quan đến tranh chấp về phân định biển do bản thân các đảo tranh chấp cũng có vùng biển riêng của mình ${ }^{9}$. Từ góc độ địa chính trị, cả hai quần đảo Hoàng Sa và Trường $S a$ đều có vị trí chiến lược. Nhiều ý kiến cho rằng việc nắm giữ hai quần đảo này đồng nghĩa với việc khống chế các tuyến hàng hải quan trọng tại Biển Đông, hay giành được ưu thế quân sự khi có xung đột ở Biển Đông. Đây có lẽ là yếu tố làm cho tranh chấp chủ quyền đối với hai quần đảo, đặc biệt là Trường $\mathrm{Sa}$, được các quốc gia bên ngoài khu vực quan tâm, xuất phát từ lợi ích duy trì tự do hàng hải ở Biển Đông ${ }^{10}$.

Tình hình căng thẳng và nguy cơ xung đột phát sinh từ các tranh chấp chủ quyền đối với hai quần đảo Hoàng $\mathrm{Sa}$ và quần đảo Trường $\mathrm{Sa}$ thường bắt nguồn từ hành vi sử dụng vũ lực để chiếm đóng các vị trí mới hoặc củng cố sự hiện

\footnotetext{
${ }^{8}$ Thông thường, các tranh chấp về chủ quyền đảo được giải quyết theo các nguyên tắc về thụ đắc lãnh thổ còn các tranh chấp liên quan đến phân định biển được giải quyết theo các nguyên tắc phân định của luật biển quốc tế. Tuy nhiên, trong một số trường hợp hãn hữu, tòa án quốc tế cho rằng giữa hai bên đã tồn tài một thỏa thuận "ngầm" về đường phân định ranh giới biển. Trong những trường hợp như vậy, tòa án thực tế sử dụng nguyên tắc giống như nguyên tắc thụ đắc lãnh thổ mà không phải là nguyên tắc phân định biển.

${ }^{9} \mathrm{Cụ} \mathrm{thể} \mathrm{trong} \mathrm{trường} \mathrm{hợp} \mathrm{quần} \mathrm{đảo} \mathrm{Trường} \mathrm{Sa}$, vấn đề phân định có thể nảy sinh trong các tình huống sau: Một là phân định giữa vùng biển của các đảo trong quần đảo này và vùng biển của các quốc gia ven biển. Hai là trong trường hợp các đảo trong quần đảo Trường Sa không thuộc chủ quyền một nước, sẽ có thể nảy sinh vấn đề phân định ngay giữa các đảo này với nhau. Trong cả hai trường hợp này, số lượng các vùng chồng lấn tạo bởi các đảo trong quần đảo Trường Sa còn phụ thuộc vào việc xác định quy chế pháp lí của chính các đảo này, cụ thể là các đảo này có vùng đặc quyền kinh tế hay thềm lục địa hay không.
}

diện trên thực địa và khẳng định các yêu sách bằng cách đơn phương áp đặt luật lệ quốc gia và cưỡng chế thi hành bằng sức mạnh tại các vùng biển lân cận hai quần đảo ${ }^{11}$. Tình hình tranh chấp phức tạp tại Biển Đông và nguy cơ bùng phát xung đột do tranh chấp không được kiểm soát, đe dọa hòa bình, an ninh, ổn định và phát triển ở Đông Nam Á là vấn đề được đặt ra đã lâu, nhất là từ thập kỷ 1990 trở lại đây. Việc Trung Quốc tiếp tục dùng Đường lưỡi bò làm cơ sở pháp lí để đe dọa và uy hiếp các nước ven Biển Đông, trong đó có Việt Nam. Trung Quốc tranh chấp quyền quản lý và sử dụng tất cả các quần đảo và vùng biển nằm trong yêu sách đó, có nghĩa là đối với gần như toàn bộ Biển Đông, có những nơi đến sát bờ biển của quốc gia ven biển khác. Yêu sách này tiếp tục được Trung Quốc theo đuổi bất chấp sự phản đối của các nước có yêu sách lẫn không có yêu sách đối với hai quần đảo. Trung Quốc đã tuyên bố xếp lợi ích của mình ở Biển Đông là "lợi ích cốt lõi”- ngụ ý rằng Trung Quốc sẵn sàng sử dụng vũ lực để bảo vệ quyền lợi của mình [4] Trung Quốc "khó chịu" với sự can dự của Mĩ cũng như các nước thứ ba khác vào Biển Đông, khẳng định các tranh chấp ở Biển Đông là vấn đề của riêng Trung Quốc với các bên tranh chấp. Trên thực địa, Trung Quốc đẩy mạnh các hoạt động trong tất cả các lĩnh vực từ đánh cá, nghiên cứu khoa học đến thăm dò khai thác dầu khí với

\footnotetext{
${ }^{10}$ Tranh chấp chủ quyền đối với Hoàng Sa là tranh chấp song phương giữa Việt Nam và Trung Quốc. Cái khó của tranh chấp này không phải ở chỗ có thể tìm ra căn cứ lịch sử và pháp lý thỏa đáng để phân định chủ quyền hay không mà ở thái độ không chấp nhận thương lượng để tìm giải pháp của một bên tranh chấp. Đến nay, Trung Quốc vẫn cho rằng ở Hoàng Sa không tồn tại tranh chấp, còn tranh chấp ở quần đảo Trường Sa là tranh chấp đa phương. Các bên tham gia tranh chấp có yêu sách không đồng nhất và trừ Brunay đều đang chiếm giữ một phần quần đảo này. Không những vậy, ở quần đảo Trường Sa còn tồn tại sự không rõ ràng về quy chế pháp lí của từng vị trí đảo đơn lẻ, cụ thể là chúng có vùng đặc quyền kinh tế và thềm lục địa riêng không.

${ }^{11}$ Có nhiều lí do dẫn đến việc căng thẳng gia tăng ở Biển Đông nhưng có hai lí do quan trọng nhất và liên quan với nhau là: (i) Sự kém hiệu quả của DOC 2002 trong việc điều chỉnh hành vi của các bên tranh chấp và (ii) Thái độ "áp đặt" hơn của Trung Quốc trong các vấn đề ở Biển Đông.
} 
những động thái khác nhau. Trong lĩnh vực dầu khí, ngoài việc đầu tư lớn để nâng cao khả năng thăm dò, khai thác ở Biển Đông, Trung Quốc còn gây sức ép với các tập đoàn dầu khí nước ngoài buộc họ rút khỏi các dự án trong khu vực và sẵn sàng tiến hành cản phá trên thực địa hoạt động thăm dò, khai thác của các quốc gia khác, kể cả ở những khu vực không lân cận hai quần đảo bị tranh chấp ${ }^{12}$. Bằng yêu sách phi lí và mập mờ về căn cứ pháp lí lẫn lịch sử, Trung Quốc đã mở rộng tranh chấp ra gần như toàn bộ Biển Đông và có những hoạt động cản trở, đe dọa việc sử dụng hòa bình và hợp pháp Biển Đông của các quốc gia khác.

Như vậy, Biển Đông không chỉ là vấn đề tranh chấp chủ quyền và quyền chủ quyền trên biển mà còn gắn với nhiều nội dung liên quan như pháp lí, an toàn hàng hải, kết nối giao thông, phát triển bền vững biển (trong những năm qua, chủ đề thường xuyên được đề cập trong tranh chấp Biển Đông là tự do hàng hải). Và những hành động mang tính hung hăng, áp đặt yêu sách cộng với thông tin về việc tăng cường mạnh mẽ ngân sách và lực lượng hải quân của Trung Quốc gây ra một chuỗi phản ứng lo ngại trong khu vực. Vì vậy, đã có nhiều nỗ lực quốc tế và khu vực, ở những cấp độ khác nhau, nhằm nghiên cứu và kiến nghị biện pháp khống chế nguy cơ xung đột ở Biển Đông; nhiều văn kiện, tuyên bố đơn phương, song phương, đa phương đã đề cập đến vấn đề này. Xây dựng một Bộ Quy tắc Ứng xử (Code of Conduct- COC) ở Biển Đông là phương thức khống chế xung đột được bàn thảo từ những năm cuối thập kỷ 1990, kết quả cụ thể là Trung

\footnotetext{
12 Đó là các sự kiện đầu 3/2011 khi tàu tuần tra của của Trung Quốc cản phá hoạt động của tàu thăm dò của Philíppin tại Bãi Cỏ Rong dẫn đến việc hải quân Philíppin phải điều máy bay chiến đầu ra hộ tống tàu thăm dò của Philíppin. Tháng 5/2014, Trung Quốc kéo giàn khoan Hải Dương 981 vào khu vực Biển Đông gần quần đảo Hoàng $\mathrm{Sa}$, nơi mà Việt $\mathrm{Nam}$ và Trung Quốc đều khẳng định đây là vùng biển thuộc chủ quyền của mình để thăm dò dầu khí. Tháng 6/2019 tàu cảnh sát biển 35111 của Trung Quốc đã thực hiện các hành vi khiêu khích xung quanh dàn khoan Hakuryu-5 ở lô 06-01 thuộc Dự án Nam Côn Sơn, liên doanh của Việt Nam với Nga. Từ 3/7/2019 tàu thăm dò địa chất Hải Dương 8 cùng với các tàu hải giám của Trung Quốc đã tiến hành khảo sát, thăm dò ở khu vực Bãi Tư Chính - vùng đặc quyền kinh tế và thềm lục địa của Việt Nam.
}

Quốc và 10 nước ASEAN ký kết Tuyên bố về Ứng xử của các Bên tại Biển Đông năm 2002 (Declaration on the Conduct of Parties in the South China Sea - DOC 2002) $)^{13}$. Trên thực tế, DOC 2002 chậm được triển khai, không được các bên triệt để tuân thủ và trong những năm gần đây đã không giúp hạn chế các hành động gia tăng căng thẳng ở Biển Đông, gây lo ngại cho các nước trong và ngoài khu vực. Đến năm 2017, ASEAN và Trung Quốc đã đạt được một mốc quan trọng trong việc giải quyết tranh chấp trên Biển Đông là thông qua dự thảo về $\mathrm{COC}$.

\section{c) Phán quyết của Tòa Trọng tài quốc tế}

Từ tháng $1 / 2013$, Philipines đã chính thức kiện Trung Quốc ra Tòa trọng tài quốc tế và tháng 3/2014 đã nộp hồ sơ chi tiết (Trung Quốc từ chối tham dự phiên tòa quốc tế này). Sáng kiến này của Philippines đã được Liên minh châu Âu và Hoa Kỳ ủng hộ nhưng các quốc gia ASEAN lại không đồng nhất ủng hộ. Sau một quá trình xem xét vụ kiện của Philippin chống lại yêu sách chủ quyền "Đường chín đoạn" của Trung Quốc ở Biển Đông, ngày 12/7/2016, Tòa Trọng tài thường trực được thành lập theo Phụ lục VII Công ước Liên Hợp quốc về Luật biển năm 1982 ở The Hague, Hà Lan (sau đây gọi tắt là Tòa Trọng tài $)^{14}$ đã ra Phán quyết dài 497 trang căn cứ vào Điều 296 của UNCLOS 1982 và Điều 11 của Phụ lục VII của UNCLOS 1982 bác bỏ yêu sách chủ quyền của Trung Quốc, tuyên bố Philippines thắng kiện về vấn đề Biển Đông và yêu sách đường lưỡi bò của Trung Quốc không có cơ sở pháp lí cũng như Trung Quốc không có “quyền

\footnotetext{
${ }^{13}$ Sau hơn 3 năm không giải quyết được vấn đề này, ASEAN và Trung Quốc đã đồng ý "hạ cấp" COC xuống thành DOC được kí tại Phnôm Pênh ngày 04/11/2002. Văn bản DOC 2002 không nêu rõ phạm vi áp dụng của các biện pháp ASEAN và Trung Quốc thỏa thuận để xây dựng lòng tin. Ngoài ra, so với dự thảo COC của ASEAN, DOC còn bỏ đi quy định về việc không xây dựng các cấu trúc mới trên những đảo, đá, bãi ngầm,... chưa có người đến ở dù vẫn giữ quy định về việc không đưa người đến ở tại những đảo, đá, bãi ngầm này.

${ }^{14}$ Tòa Trọng tài này còn được gọi là Hội đồng Trọng tài nhưng một số người khác lại cho rằng phán quyết này là của Tòa Trọng tài Thường trực.
} 
lịch sử” với các tài nguyên nằm trong vùng biển trong Đường chín đoạn" ở Biển Đông ${ }^{15}$.

Tuy nhiên, Trung Quốc không công nhận phán quyết của Tòa và tuyên bố sẽ tiếp tục bảo vệ quyền lợi của họ, Philipines thắng kiện nhưng không làm thay đổi được hiện tình ở Biển Đông. Trung Quốc một mặt ra sức công kích các thẩm phán và tỏ vẻ "phớt lờ" phán quyết; mặt khác, tìm mọi cách, trong đó có cả việc sử dụng các nhà khoa học để tìm cách chứng minh cho yêu sách đã bị phán quyết bác bỏ. Trên thực địa, Trung Quốc tiếp tục đẩy mạnh quân sự hóa và gia tăng xâm nhập vào vùng biển của các quốc gia khác nhưng âm thầm, lặng lẽ hơn. Phán quyết của Tòa trọng tài là một trong những trở ngại lớn của Trung Quốc trên con đường tìm cách độc chiếm Biển Đông. Mặc dù phán quyết của Tòa trọng tài ngày 12/7/2016 có tác dụng làm giảm khu vực tranh chấp, qua đó thu hẹp không gian cho các hoạt động chấp pháp và dân sự của Trung Quốc, nhưng phán quyết không có tác động đến các hoạt động quân sự, không ảnh hưởng đến sự mở rộng, tăng cường kiểm soát về quân sự, an ninh, chiển lược của Trung Quốc ở Biển Đông. Quan trọng hơn, việc thiếu vắng cơ chế thực thi phán quyết cùng với sự thay đổi chính sách của Philíppin giúp Trung Quốc giành lại thế chủ động trên bàn cờ ngoại giao và chiến lược ở Biển Đông. Trung Quốc đã chuẩn bị rất kỹ để đối phó và phản ứng rất quyết liệt (trong cả lời nói và hành động) với Phán quyết của Tòa Trọng tài. Điều này cho thấy: Trung Quốc kiên

\footnotetext{
${ }^{15}$ Những điểm chính trong Phán quyết của Tòa Trọng tài bao gồm: 1) Trung Quốc không có "quyền lịch sử" đối với Biển Đông; 2) "Đường chín đoạn" do Trung Quốc tự vẽ ra không phù hợp với UNCLOS 1982; 3) Không có thực thể nào ở quần đảo Trường Sa có thể mang lại vùng đặc quyền kinh tế cho Trung Quốc; 4) Trung Quốc can thiệp vào quyền đánh bắt cá của ngư dân Philippin, đặc biệt là ở bãi cạn Scarborough; 5) Trung Quốc gây thiệt hại đến hệ sinh thái quần đảo Trường $\mathrm{Sa}$ bằng các hoạt động như khai thác quá mức, xây đảo nhân tạo; 6) Các hành động của Trung Quốc làm gia tăng khả năng xảy ra xung đột với Philippin. Ngoài ra, Phán quyết của Tòa Trọng tài khẳng định "Phán quyết này có tính ràng buộc pháp lí và có tính chung thẩm”. Như vậy, Phán quyết của Tòa Trọng tài đã không công nhận tính pháp lí trong yêu sách chủ quyền của Trung Quốc ở Biển Đông và Philippin đã trở thành bên thắng kiện.
}

quyết bám giữ quan điểm và yêu sách chủ quyền phi lí ở Biển Đông và đây tiếp tục sẽ là những quan ngại của cộng đồng quốc tế đối với tình hình an ninh - chính trị ở vùng biển này. Theo đó, tình hình Biển Đông tuy bình lặng trên mặt nhưng hết sức nguy hiểm bởi sóng ngầm vần cuộn chảy mạnh mẽ. Trung Quốc giữ trạng thái tương đối ôn hòa về vấn đề Biển Đông bằng cách lặng lẽ hoàn thành 7 hòn đảo nhân tạo ở quần đảo Trường $\mathrm{Sa}^{16}$ và cố gắng kiềm chế không thực hiện các hành động hung hăng quy mô lớn. Bắc Kinh thậm chí còn thể hiện thiện chí và nỗ lực thúc đẩy các cuộc thảo luận với ASEAN về việc xây dựng một Bộ Quy tắc ứng xử dành cho vùng biển này. Theo nhận định của các chuyên gia, Trung Quốc được xem là đang áp dụng một biện pháp hai gọng kìm nhằm thiết lập sự kiểm soát trên thực tế đối với Biển Đông: Một mặt, Trung Quốc đẩy mạnh quân sự hóa các tiền đồn của mình, đặc biệt là 7 hòn đảo nhân tạo tại Quần đảo Trường $\mathrm{Sa}$, nhằm tăng cường năng lực triển khai sức mạnh quân sự của mình và răn đe chống lại các đối thủ trên biển. Mặt khác, Bắc Kinh đã tinh gọn hóa các lực lượng trên biển và củng cố cơ cấu chỉ huy của chúng để thực thi quyền kiểm soát trên biển hiệu quả hơn. Những dấu hiệu như trên đã làm gia tăng căng thẳng và thúc đẩy tình trạng quân sự hóa tranh chấp, làm tăng nguy cơ đụng độ vũ trang trong khu vực và hoàn toàn không phải là điềm tốt cho tình hình Biển Đông. Điều đó cũng sẽ kích thích phản ứng từ các chủ thể trong khu vực, bao gồm cả Hoa Kỳ và Nhật Bản ${ }^{17}$.

\footnotetext{
${ }^{16}$ Trung Quốc xây đảo nhân tạo trên quần đảo Trường Sa, cơi nới quần đảo Hoàng $\mathrm{Sa}$, gồm: (1). Biến đá Chữ Thập thành đảo nhân tạo lớn; (2) Biến đá Xu Bi thành đảo nhân tạo trên Biển Đông lớn thứ hai về diện tích và lớn nhất về quy mô xây dựng công trình; (3) Biến đá Vành Khăn thành đảo hoàn toàn nhân tạo có diện tích lớn nhất trên Biển Đông (kể cả đảo, đá tự nhiển); (4) Cải tạo bãi Châu Viên; (5). Xây đảo tại đá $\mathrm{Gạc} \mathrm{Ma;} \mathrm{(6)} \mathrm{Xây} \mathrm{cất} \mathrm{tại} \mathrm{bãi} \mathrm{đá} \mathrm{Ga} \mathrm{Ven} \mathrm{và} \mathrm{đá} \mathrm{Lạc;}$ (7). Bồi đắp đá Tư Nghĩa; (8). Cơi nới các đảo ở Hoàng Sa. ${ }^{17}$ Như: sau khi xuất hiện các báo cáo về việc triển khai tên lửa của Trung Quốc, Nhà Trắng đã cảnh báo rằng Bắc Kinh sẽ phải đối mặt với hậu quả vì hành động gia tăng quân sự hóa tranh chấp Biển Đông của mình. Đối với Việt Nam, việc Trung Quốc triển khai tên lửa trên ba hòn đảo nhân tạo đặt ra một mối đe dọa đáng kể cho các điểm đảo mà Việt Nam đang nắm giữ tại Quần đảo Trường $\mathrm{Sa}$, cũng như căn cứ hải quân tại vịnh Cam Ranh, vốn được cho là nằm trong
} 


\section{Vai trò của chính sách, pháp luật (các) quốc gia về khai thác, sử dụng biển Đông}

Chính sách và pháp luật là những công cụ quan trọng để các quốc gia thực thi quản lí nhà nước về biển (đảo). Trên cơ sở những nghiên cứu, luận giải những vấn đề cơ bản về chính sách, pháp luật đồng thời phân tích, nhận diện những vấn đề thực tiễn ở Biển Đông hiện nay, có thể thấy vai trò của chính sách, pháp luật các quốc gia về sử dụng, khai thác Biển Đông được thể hiện ở những nội dung chủ yếu như sau:

a) Chính sách, pháp luật là công cu để các quốc gia bảo vệ độc lập chủ quyền, quyền chủ quyền, quyền tài phán quốc gia, sự toàn vẹn lãnh thổ và thực thi các muc tiêu quốc gia về sủ dụng, khai thác Biển Đông

Hệ thống chính sách pháp luật, trước hết là chính sách pháp luật về quản lí, thực thi và bảo vệ chủ quyền biển đảo là những cơ sở pháp lí và công cụ quản lí để các quốc gia trong khu vực Biển Đông bảo vệ độc lập, chủ quyền, quyền chủ quyền, quyền tài phán và sự toàn vẹn lãnh thổ của quốc gia, bao gồm: đất liền, vùng trời, vùng biển, nội thủy, lãnh hải, thềm lục địa, vùng đặc quyền kinh tế của quốc gia.

Ngoài ra, xây dựng và thực thi các chính sách, pháp luật của các quốc gia trong hoạt động khai thác, sử dụng biển Đông nhằm để hiện thực hóa các mục tiêu quốc gia về khai thác, sử dụng Biển Đông, phục vụ công cuộc xây dựng, phát triển đất nước. Hoa Kỳ: là nước công khai tuyên bố ủng hộ tự do hàng hải trên Biển Đông và giải quyết mọi tranh chấp trên Biển Đông bằng biện pháp hòa bình. Cựu ngoại trưởng Mĩ Hillary Clinton đã lên tiếng ủng hộ quyền tự do hàng hải bằng cách nhắc lại rằng "tự do hàng hải và tôn trọng luật pháp quốc tế" là một vấn đề thuộc lợi ích quốc gia của Mĩ. Hoa Kỳ thường xuyên tiến hành nhiều cuộc tuần tra bảo vệ tự do hàng hải trong vùng Biển Đông và tham gia tập trận với nhiều nước trong khu vực. Tháng 5/2014, chính

tầm bắn của tên lửa Trung Quốc. Trong khi đó, việc quân sự hóa lực lượng Hải Cảnh của Trung Quốc có nghĩa là các cuộc đụng độ trong tương lai giữa lực lượng này với các lực lượng trên biển của Việt Nam sẽ có nguy cơ tạo ra căng thẳng lớn hơn và khả năng đối đầu vũ trang cao hơn. phủ Mĩ đã đề xuất khoản ngân sách 1,2 tỉ USD dành cho các hoạt động tại khu vực Đông Á-Thái Bình Dương năm 2015, bao gồm hơn 800 triệu USD cho các chương trình hỗ trợ nước ngoài, trong đó sẽ cung cấp 18 triệu USD cho cảnh sát biển Việt Nam. Tháng 11/2018 - đúng thời điểm chủ tịch Trung Quốc Tập Cận Bình thăm Philippines ${ }^{18}$, quân đội Mĩ tồ chức một cuộc tập trận có quy mô lớn, huy động hải quân và không quân tại Biển Đông và eo biển Đài Loan. Nhìn chung, chính sách và mục tiêu chiến lược của Mĩ đối với tranh chấp chủ quyền trên Biển Đông được thể hiện qua lập trường 4 điểm: (i) Mĩ thúc giục giải pháp tăng cường "hòa bình, thịnh vượng và an ninh" trong khu vực; (ii) Mĩ không đồng tình với việc đe dọa hoặc sử dụng vũ lực để khẳng định yêu sách về chủ quyền của bất kì nhà nước nào ở Biển Đông và coi đây là một vấn đề nghiêm trọng; (iii) Mĩ sẵn sàng giúp đỡ bằng giải pháp hòa bình đối với các yêu sách đó nếu được các bên yêu cầu; (iv) Mĩ có lợi ích chiến lược trong việc duy trì sự an toàn và tự do đối với các tuyến đường giao thông trên Biển Đông và xem đó là vấn đề cơ bản để không đồng tình về bất kì yêu sách về chủ quyền biển của quốc gia nào không phù hợp với Công ước Liên Hợp quốc về Luật biển năm 1982.

Hoa Kỳ: là nước công khai tuyên bố ủng hộ tự do hàng hải trên Biển Đông và giải quyết mọi tranh chấp trên Biển Đông bằng biện pháp hòa bình. Cựu ngoại trưởng Mĩ Hillary Clinton đã lên tiếng ủng hộ quyền tự do hàng hải bằng cách nhắc lại rằng "tự do hàng hải và tôn trọng luật pháp quốc tế" là một vấn đề thuộc lợi ích quốc gia của Mĩ. Hoa Kỳ thường xuyên tiến hành nhiều cuộc tuần tra bảo vệ tự do hàng hải trong vùng Biển Đông và tham gia tập trận với nhiều nước trong khu vực. Tháng 5/2014, chính phủ Mĩ đã đề xuất khoản ngân sách 1,2 tỉ USD dành cho các hoạt động tại khu vực Đông Á-Thái Bình Dương năm 2015, bao gồm hơn 800 triệu USD

\footnotetext{
${ }^{18}$ Người phát ngôn Bộ Ngoại giao Hoa Kỳ phát biểu rằng Hoa Kỳ quan ngại sâu sắc với việc hạ đặt giàn khoan của Trung Quốc tại vùng biển mà Việt Nam cũng đòi hỏi. Bộ trưởng Ngoại giao John Kerry công khai gọi hành động của Trung Quốc là "khiêu khích" và "hung hăng"...
} 
cho các chương trình hỗ trợ nước ngoài, trong đó sẽ cung cấp 18 triệu USD cho cảnh sát biển Việt Nam. Tháng 11/2018 - đúng thời điểm chủ tịch Trung Quốc Tập Cận Bình thăm Philippines ${ }^{19}$, quân đội Mĩ tổ chức một cuộc tập trận có quy mô lớn, huy động hải quân và không quân tại Biển Đông và eo biển Đài Loan. Nhìn chung, chính sách và mục tiêu chiến lược của Mĩ đối với tranh chấp chủ quyền trên Biển Đông được thể hiện qua lập trường 4 điểm: (i) Mĩ thúc giục giải pháp tăng cường "hòa bình, thịnh vượng và an ninh" trong khu vực; (ii) Mĩ không đồng tình với việc đe dọa hoặc sử dụng vũ lực để khẳng định yêu sách về chủ quyền của bất kì nhà nước nào ở Biển Đông và coi đây là một vấn đề nghiêm trọng; (iii) Mĩ sẵn sàng giúp đỡ bằng giải pháp hòa bình đối với các yêu sách đó nếu được các bên yêu cầu; (iv) Mĩ có lợi ích chiến lược trong việc duy trì sự an toàn và tự do đối với các tuyến đường giao thông trên Biển Đông và xem đó là vấn đề cơ bản để không đồng tình về bất kì yêu sách về chủ quyền biển của quốc gia nào không phù hợp với Công ước Liên Hợp quốc về Luật biển năm 1982.

Trung Quốc: khẳng định chủ quyền trên Biển Đông không chỉ có ý nghĩa về mặt quyền lợi kinh tế mà còn cả ý nghĩa về mặt chính trị - lịch sử đối với quốc gia này. Trung Quốc đã nhiều lần tuyên bố có chủ quyền lịch sử với một số khu vực ở Biển Đông, trong đó có quần đảo Hoàng $\mathrm{Sa}$ và Trường $\mathrm{Sa}, \ldots$ Với vai trò là nước có sức mạnh nhất và có liên quan tới ba cuộc xung đột quân sự trong khu vực tranh chấp lãnh thổ, chính sách của Trung Quốc đóng vai trò quan trọng trong định hình những việc diễn biến sắp tới của tranh chấp cũng như đối với tình hình an ninh khu vực. Trong tương lai gần, Bắc Kinh có khả năng sẽ áp dụng chính sách quyết đoán nhưng không đối đầu trong tranh chấp Biển Đông.

ASEAN: có diện tích 4,5 triệu $\mathrm{km}^{2}$, dân số khoảng 575 triệu người và tổng sản phẩm quốc nội (GDP) đạt khoảng 3.000 tỉ USD, đang được

\footnotetext{
${ }^{19}$ Người phát ngôn Bộ Ngoại giao Hoa Kỳ phát biểu rằng Hoa Kỳ "quan ngại sâu sắc" với việc hạ đặt giàn khoan của Trung Quốc tại vùng biển mà Việt Nam cũng đòi hỏi. Bộ
}

đánh giá là nơi có sự phát triển kinh tế năng động bậc nhất và có sức hấp dẫn lớn tại khu vực Châu Á - Thái Bình Dương. Sự ổn định và phát triển của hầu hết các quốc gia ASEAN đang phụ thuộc chủ yếu vào tuyến đường hàng hải trên biển Đông. Tuy nhiên, nếu ASEAN không nhận thức đầy đủ, đoàn kết cùng đối phó lại với thách thức, đe dọa từ phía Trung Quốc thì những thập kỉ ổn định và phát triển của ASEAN sẽ không còn được kéo dài. Các chuyên gia phân tích chính trị thế giới đều có chung nhận định: ASEAN đóng vai trò rất quan trọng trong việc giải quyết vấn đề Biển Đông, nhưng vai trò này chỉ có được khi có sự đoàn kết của các nước thành viên ASEAN trong thống nhất hành động trước thách thức từ phía Trung Quốc. Khi ASEAN đoàn kết đưa ra lập trường chung thì tiếng nói của tổ chức khu vực này sẽ có trọng lượng, được lắng nghe, được xem trọng. Ngược lại, nếu ASEAN bị li gián và bị phân hóa, thì tiếng nói của ASEAN sẽ bị suy yếu, bị nước lớn chi phối. Nhiều chuyên gia phân tích chính trị cho rằng, chỉ có $\mathrm{ASEAN}$ mới có thể giải quyết chính vấn đề của ASEAN. Muốn làm được điều này, ASEAN nhất thiết phải thống nhất hành động, phát huy vai trò của khối trong việc xử lí vấn đề Biển Đông. Bởi với khả năng huy động, triệu tập lực lượng dưới lá cờ chung ASEAN, đồng thời dựa vào sự đồng bộ tương đối về lợi ích chính trị (cùng có chủ quyền trên Biển Đông), kinh tế (thế mạnh lúa gạo, nông sản...) và môi trường (sở hữu chung sông Mê Kông), ASEAN mới có thể xây dựng được sức mạnh tập thể nhằm giành lại "thế cân bằng" trước hành động ngang ngược cá lớn nuốt cá bé và bất chấp luật pháp quốc tế của Trung Quốc. Cũng chỉ có thể bằng chính sự đoàn kết của mình, xây dựng "con đê chắn sóng" vững chắc ngăn chặn con sóng dữ từ sự bá quyền tiến xuống phía Nam của Trung Quốc, ASEAN mới tranh thủ được sự ủng hộ của cộng đồng quốc tế trong giải quyết vấn đề căng thẳng trên Biển Đông.

trưởng Ngoại giao John Kerry công khai gọi hành động của Trung Quốc là "khiêu khích" và "hung hăng"... 
Các bước xác định mục tiêu chính sách

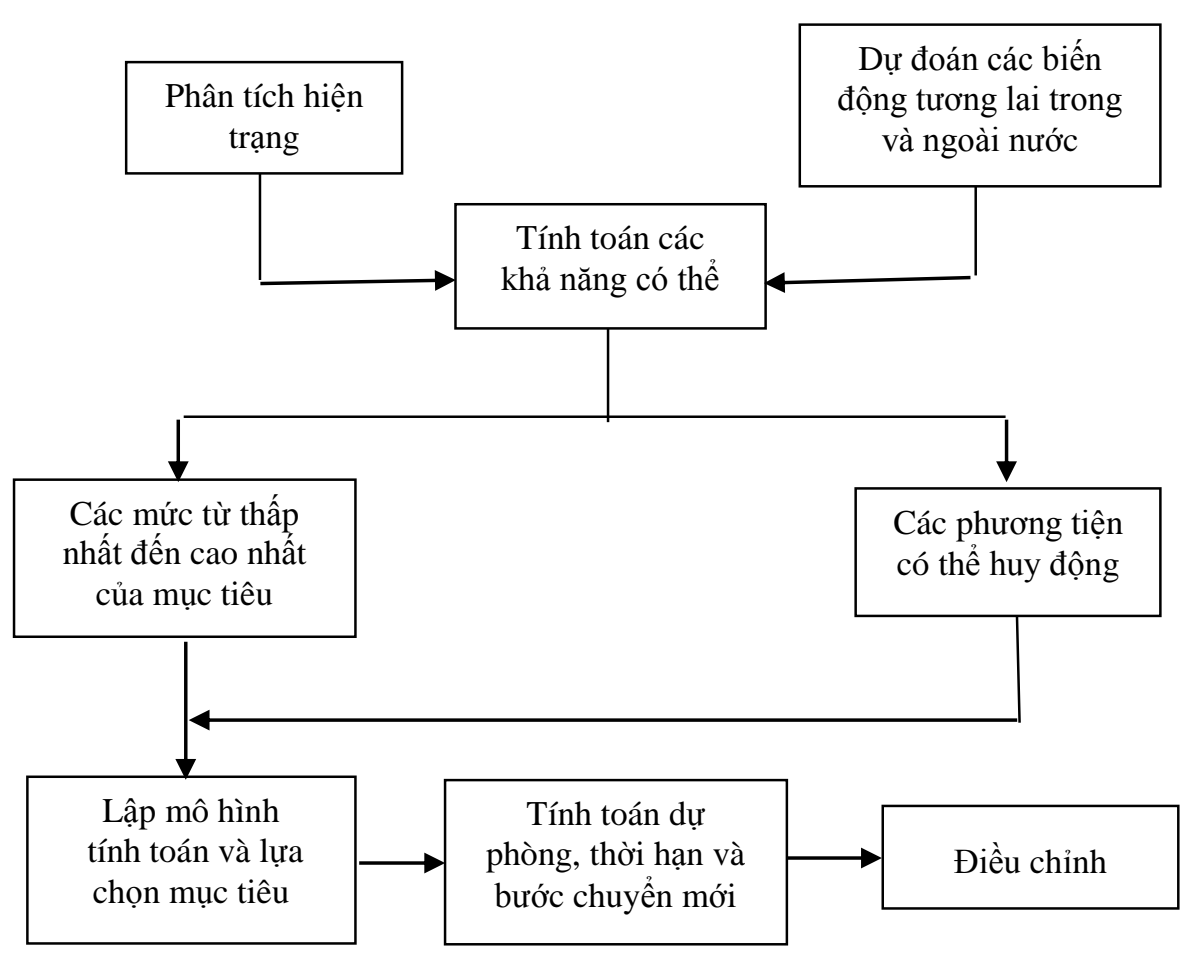

\section{Chính sách biển, đảo của Việt Nam}

Việt Nam nằm phía Tây biển Đông, có bờ biển dài khoảng $3260 \mathrm{~km}$, nằm trên đường hàng hải chiến lược về giao lưu, thương mại quốc tế giữa Ấn Độ Dương và Thái Bình Dương, nơi tập trung nhiều nguồn tài nguyên thiên nhiên, chiếm tới $1 / 3$ toàn bộ đa dạng sinh học biển thế giới. Đối với Việt Nam, biển, đảo không chỉ là bộ phận cấu thành chủ quyền, quyền chủ quyền thiêng liêng của Tổ quốc mà còn là không gian sinh tồn và phát triển của các thế hệ người Việt Nam; các vùng biển của Việt Nam có vị trí địa chính trị, địa quân sự, địa kinh tế quan trọng trong khu vực và trên thế giới.

Là quốc gia biển trong khu vực Biển Đông, Việt Nam với vị thế đặc thù: vùng biển Việt Nam chiếm gần $1 / 3$ diện tích, là "ban công" hướng ra biển Thái Bình Dương, có nhiều thuận lợi cho hoạt động giao thương và hội nhập quốc tế

\footnotetext{
${ }^{20}$ Như: Chiến lược phát triển bền vững kinh tế biển Việt Nam đến năm 2030, tầm nhìn đến năm 2045 do Hội nghị lần thứ tám Ban Chấp hành Trung ương khóa XII đề ra.
}

nhưng cũng là vị trí xung yếu về mặt an ninhquốc phòng; tạo cho Việt Nam một vị thế địa - chính trị và địa - kinh tế then chốt trong chiến lược phát triển, mở rộng ảnh hưởng các nước lớn trên thế giới, từ xa xưa cho đến nay. Từ thế đứng tự nhiên - lịch sử, cùng với vị thế của đất nước hiện nay trong khu vực và trên thế giới, Việt Nam đã có nhiều chủ trương, chính sách về biển, sách nhằm khai thác tối đa tiềm năng và lợi thế trên biển, vùng ven biển và hải đảo, bảo đảm quốc phòng an ninh, bảo vệ môi trường, bảo vệ toàn vẹn chủ quyền quốc gia, góp phần đẩy nhanh sự nghiệp công nghiệp hóa, hiện đại hóa, đưa Việt Nam trở thành "quốc gia mạnh về biển, giàu từ biển, phát triển bền vững, thịnh vượng, an ninh và an toàn" ${ }^{20}$. Bằng việc phê chuẩn Công ước Liên Hợp quốc về Luật Biển năm 1982, Việt Nam biểu thị sự quyết tâm cùng cộng đồng quốc tế xây dựng một trật tự công bằng, khuyến khích sự 
phát triển và hợp tác trên biển. Việt Nam đã nhiều lần nêu rõ sự lo ngại về những diễn biến phức tạp ở Biển Đông, trong đó có việc vi phạm các quyền chủ quyền, quyền tài phán tại các vùng biển của Việt Nam được xác định theo UNCLOS 1982. Việt Nam cũng ủng hộ mọi nỗ lực thực hiện các biện pháp hòa bình giải quyết tranh chấp theo Hiến chương Liên Hợp quốc và luật pháp quốc tế, từ thương lượng, hòa giải tới việc sử dụng các cơ chế pháp lí quốc tế.

b) Chính sách, pháp luật của các quốc gia về sử dụng, khai thác biển Đông tác động đến việc duy trì và thực thi luật pháp và tập quán quốc tế

Như: Hiến chương Liên Hợp quốc, Công ước Liên Hợp quốc về Luật Biển United Nations, phán quyết của Tòa án Trọng tài thường trực tại Hà Lan ngày $12 / 7 / 2016$.

Hiến chương được xem như là bản hiến pháp của Liên Hợp quốc ${ }^{21}$, đã được hầu hết các quốc gia trên thế giới thông qua. Hiến chương đã khẳng định mục đích của Liên Hợp quốc là: (i). Duy trì hòa bình và an ninh quốc tế, và để đạt được mục đích đó, thi hành những biện pháp tập thể có hiệu quả để phòng ngừa và loại trừ các mối đe dọa hòa bình, cấm mọi hành vi xâm lược và phá hoại hòa bình khác; điều chỉnh hoặc giải quyết các vụ tranh chấp hoặc những tình thế có tính chất quốc tế có thể đưa đến sự phá hoại hòa bình, bằng phương pháp hòa bình theo đúng nguyên tắc của công lí và pháp luật quốc tế; (ii). Phát triển mối quan hệ hữu nghị giữa các dân tộc trên cơ sở tôn trọng nguyên tắc bình đẳng và tự quyết của các dân tộc và áp dụng những biện pháp phù hợp khác để củng cố hòa bình thế giới; (iii). Thực hiện sự hợp tác quốc tế trong việc giải quyết các vấn đề quốc tế về kinh tế, xã hội, văn hoá và nhân đạo và khuyến khích phát triển sự tôn trọng các quyền của con người và các tự do cơ bản cho tất cả mọi người không phân biệt chủng tộc, nam nữ, ngồn ngữ hoặc tôn giáo; (iv) Trở thành trung tâm phối

\footnotetext{
${ }^{21}$ Hiến chương Liên Hợp quốc được kí kết trong Hội nghị Liên Hợp quốc về Tổ chức Quốc tế tại San Francisco, California ngày 26/6/1945 bởi 50 nước thành viên đầu tiên, có hiệu lực từ ngày 24/10/1945 sau khi được phê chuẩn bởi 5 nước thành viên sáng lập (gồm Trung Hoa
}

hợp mọi hành động của các dân tộc, nhằm đạt được những mục đích chung nói trên (Điều 1).

Để đạt được những mục đích nêu trên, Liên Hợp quốc và các thành viên hành động phù hợp với những nguyên tắc bình đẳng chủ quyền của tất cả các quốc gia. Các thành viên Liên Hợp quốc giải quyết các tranh chấp quốc tế của họ bằng biện pháp hòa bình, sao cho không tổn hại đến hòa bình, an ninh quốc tế và công lí; từ bỏ đe dọa bằng vũ lực hoặc sử dụng vũ lực trong quan hệ quốc tế nhằm chống lại sự bất khả xâm phạm về lãnh thổ hay nền độc lập chính trị của bất kì quốc gia nào cũng như bằng cách khác trái với những mục đích của Liên Hợp quốc; giúp đỡ đầy đủ cho Liên Hợp quốc trong mọi hành động mà nó áp dụng theo đúng Hiến chương này và tránh giúp đỡ bất cứ quốc gia nào bị Liên Hợp quốc áp dụng các hành động phòng ngừa hoặc cưỡng chế. Liên Hợp quốc có trách nhiệm để các quốc gia không phải là thành viên Liên Hợp quốc cũng hành động theo nguyên tắc này để duy trì hòa bình và an ninh thế giới; không được can thiệp vào những công việc thực chất thuộc thẩm quyền nội bộ của bất cứ quốc gia nào... (Điều 2).

Cùng với Hiến chương Liên Hợp quốc, luật pháp quốc tế là nền tảng của quan hệ bình đẳng, công bằng giữa các quốc gia; có vai trò và tầm quan trọng trong việc xây dựng một trật tự thế giới dựa trên luật lệ, thúc đẩy quan hệ giữa các quốc gia và tăng cường hợp tác đa phương. Tôn trọng các nguyên tắc cơ bản của Hiến chương Liên Hợp quốc và luật pháp quốc tế trong quan hệ quốc tế là yếu tố quyết định đảm bảo hòa bình, an ninh và là những điều kiện tiên quyết cho mọi hoạt động của cộng đồng quốc tế. Đó cũng là cách thức hữu hiệu nhằm ngăn ngừa xung đột cũng như tìm kiếm những giải pháp lâu bền cho tranh chấp, xung đột; giúp các bên và quốc gia khu vực, các quốc gia có liên quan và cộng đồng quốc tế để đạt được các giải pháp công bằng, hợp lí quyền và lợi ích. Bởi vậy, các nỗ lực đa phương

Dân quốc, Liên Xô, Pháp, Anh, Hoa Kỳ) và phần đông các nước khác. Bản Hiến chương được thảo luận bởi hội đồng lập pháp và các nước đã kí đều tuân theo các điều khoản của nó. 
cần dựa trên và hướng tới đảm bảo sự tôn trọng đối với nền tảng này. Các bên liên quan ở Biển Đông cần tuân thủ luật pháp quốc tế, kiềm chế và tránh có những hành động đơn phương làm phức tạp tình hình và gia tăng căng thẳng, và giải quyết các tranh chấp bằng các biện pháp hòa bình phù hợp với luật pháp quốc tế, trong đó có Công ước Luật biển năm 1982- Hiến chương của Biển và đại dương - Văn kiện pháp lí quốc tế quan trọng nhất kể từ sau Chiến tranh thế giới lần thứ II, được đông đảo các quốc gia thành viên Liên Hợp quốc kí kết tham gia. Ngoài ra, Phán quyết vụ kiện giữa Philippines và Trung Quốc về biển Đông của Tòa Trọng tài thường trực tại The Hague (Hà Lan) ngày 12/7/2016 cũng được xem là căn cứ pháp lí quan trọng cho Việt Nam và các quốc gia trong khu vực nghiên cứu, vận dụng để bảo vệ chủ quyền biển đảo một cách hòa bình bằng luật quốc tế trong điều kiện hội nhập quốc tế [5].

c) Chính sách, pháp luật của các quốc gia về sủ dụng, khai thác biển Đông góp phần duy trì hòa bình, an ninh, ổn định, hưu nghị hợp tác và phát triển bền vũng và góp phần đảm bảo tụ do hàng hải, tụ do hàng không ở khu vục biển Đông

Những hành động gây căng thẳng ở biển Đông của Trung Quốc đã vi phạm các quy định của Công ước luật biển năm 1982 và càng làm cho các vấn đề tranh chấp trở lên phức tạp, đe dọa đến hòa bình, ổn định và lợi ích của các quốc gia trong khu vực, an ninh môi trường biển, an toàn hàng hải hàng không ở biển Đông. Đặc biệt, đường chín đoạn phi pháp do Trung Quốc tự ý vạch ra, ôm trọn hầu hết Biển Đông. Một khi Trung Quốc hiện thực hóa tham vọng "đường lưỡi bò chín đoạn" để biến Biển Đông thành ao nhà của họ theo những đòi hỏi chủ quyền phi lí và phi pháp thì không chỉ tự do hàng hải, hàng không trên tuyến vận tải huyết mạch với nền kinh tế thế giới mà cả hòa bình, an ninh, ổn định của khu vực và toàn cầu cũng bị đe dọa nghiêm trọng. Nếu xét tham vọng hàng hải và mong muốn kiểm soát thực tế Biển Đông của Trung Quốc, các thành viền $A S E A N$ và Việt Nam có cùng mục tiêu chiến lược sẽ gặp nhiều khó khăn trong việc thương lượng với Trung Quốc. Vì vậy, đòn bẩy chính của những quốc gia này trong cuộc đàm phán có lẽ là áp lực ngày càng tăng từ Hoa Kỳ và các đồng minh đối với Trung Quốc trên vấn đề Biển Đông.

Duy trì môi trường hòa bình, ổn định, hợp tác, phát triển ở Biển Đông là bổn phận và trách nhiệm của các quốc gia và giải pháp duy nhất cho vấn đề hòa bình ở Biển Đông là sự tôn trọng và tuân thủ luật pháp quốc tế. Vì vậy, các bên liên quan cần xuất phát từ tinh thần và trách nhiệm chung cần tôn trọng luật pháp quốc tế và Công ước ước của Liên Hợp quốc về Luật Biển, chấm dứt các hành động căng thẳng, thiện chí hợp tác gìn giữ hòa bình, ổn định và phát triển ở khu vực; duy trì mẫu số lợi ích chung ASEAN, khai thác, bảo vệ tài nguyên và môi trường Biển Đông có hiệu quả trên cơ sở hợp tác quốc tế.

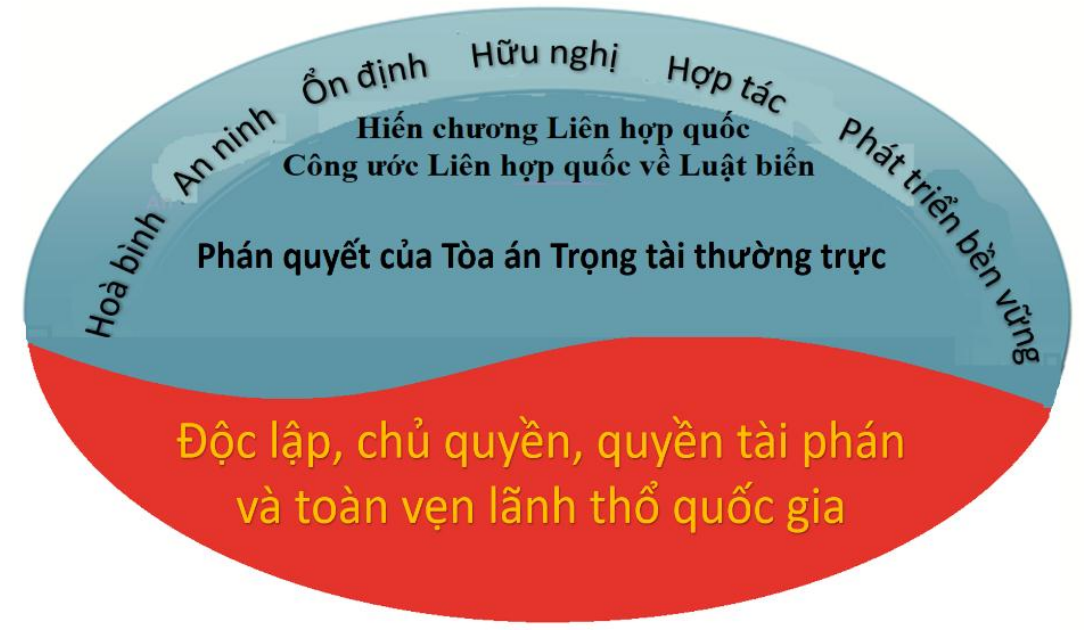




\section{Tài liệu tham khảo}

[1] Kuang-ming Jih-pao (Canton) 24 Nov. 1975 p.2, cited in Samuels.

[2] "Oil Drives Territorial Dispute in South China Sea", International Herald Tribunes, 4/24/1995.

[3] Multilateralism and the south China sea conflict: Quest for hegemonic stability?

[4] I Storey, "China's Missteps in Southeast Asia: Less Charm, More Offensive" (2010) X China Brief 4.

[5] The position of East Vietnam Sea.
[6] https://www.academia.edu/28510538/V\%E1\%BB\% 8B_th\%E1\%BA\%BF_Bi\%E1\%BB\%83n_\%C4\%90 $\% \mathrm{C} 3 \% \mathrm{~B} 4 \mathrm{ng}$

the_position_of_East_Vietnam_Sea._H\%E1\%BB $\% 99$ i_ngh\%E1\%BB\%8B_Khoa_h\%E1\%BB\%8Dc v\%C3\%A0_C\%C3\%B4ng_ngh\%E1\%BB\%87_bi\% E1\%BB\%83n_to\%C3\%A0n_qu\%E1\%BB\%91c_1\% E1\%BA\%A7n_th\%E1\%BB\%A9_V._n\%C4\%83m_ 2011._Ti\%E1\%BB\%83u_ban_\%C4\%90\%E1\%BB $\% 8 \mathrm{Ba} 1 \% \mathrm{C} 3 \%$ BD_\%C4\%90\%E1\%BB $\% 8 \mathrm{Ba} \_\mathrm{ch} \%$ E1\%BA\%A5t_v\%C3\%A0_\%C4\%90\%E1\%BB\%8 Ba_v\%E1\%BA\%ADt_1\%C3\%BD_Bi\%E1\%BB\%8 3n._Tr._59-68?email_work_card=view-paper. 